\title{
POPULATION DENSITY AND PHOTOSYNTHETIC PIGMENT CONTENT IN SYMBIOTIC DINOFLAGELLATES IN THE BRAZILIAN SCLERACTINIAN CORAL MONTASTREA CAVERNOSA (LINNAEUS, 1767)
}

\author{
Cristiane F. Costa ${ }^{1}$, Roberto Sassi ${ }^{2}$ \& Fernanda D. Amaral ${ }^{3}$
}

${ }^{1}$ Universidade Federal da Paraíba

Programa de Pós-Graduação em Ciências Biológicas/Zoologia

(Cidade Universitária - Campus I, 58059-900 João Pessoa, Paraíba, PB, Brasil) cfcosta@nepremar.ufpb.br

${ }^{2}$ Universidade Federal da Paraíba

Departamento de Sistemática e Ecologia, Centro de Ciências Exatas e da Natureza, Núcleo de Estudos e Pesquisas dos Recursos do Mar

(Cidade Universitária - Campus I, 58059-900 João Pessoa, Paraíba, PB, Brasil)

${ }^{3}$ Universidade Federal Rural de Pernambuco

Departamento de Biologia/Área de Zoologia

(Avenida Dom Manoel de Medeiros, s/n, 52171-900 Dois Irmãos, Recife, PE, Brasil)

\section{A B S T R A C T}

The seasonal dynamics of cell density and photosynthetic pigment contents of the zooxanthellae hosted by Montastrea cavernosa were investigated on coastal reefs off Picãozinho $\left(06^{\circ} 42^{\prime} 05^{\prime \prime} / 07^{\circ} 07^{\prime} 30^{\prime \prime} \mathrm{S}\right.$ and $\left.34^{\circ} 48^{\prime} 37^{\prime \prime} / 34^{\circ} 50^{\prime} 00^{\prime \prime} \mathrm{W}\right)$, Northeast Brazil between September 1999 and 2000. A distinct pattern of these parameters was found: cell numbers were greater during the rainy season (autumn/winter) while photosynthetic pigments were greater during the dry season (summer). Both parameters showed drastic reductions during heavy rains (June and July 1999). We speculate that this pattern is largely influenced by the rain cycles which, owing to their magnitude and frequency, affect the water clarity and the seasonal physiological condition of the cells.

\section{R ESUMO}

\begin{abstract}
A dinâmica sazonal na densidade de células e na concentração de pigmentos fotossintetizantes das zooxantelas de Montastrea cavernosa foram analisados no período setembro/1999 a setembro/2000 nos Recifes do Picãozinho $\left(06^{\circ} 42^{\prime} 05^{\prime \prime} / 07^{\circ} 07^{\prime} 30^{\prime \prime} \mathrm{S}\right.$ e $\left.34^{\circ} 48^{\prime} 37^{\prime \prime} / 34^{\circ} 50^{\prime} 00^{\prime \prime} \mathrm{W}\right)$, Nordeste do Brasil. Verificou-se que existe um padrão distinto entre estes parâmetros, com maior quantidade de células no período chuvoso e maior concentração de pigmentos fotossintetizantes na época de estiagem. Ambos os parâmetros apresentaram, no entanto, uma nítida redução em seus valores nos meses de maiores índices pluviométricos (junho e julho /1999). Especulamos que tal fato deve estar relacionado com o regime de chuvas que pode variar em magnitude e freqüência, afetando a qualidade ótica da água e o estado fisiológico das células.
\end{abstract}

Descriptors: Brazil, Montastrea cavernosa; Symbiotic dinoflagellates; Zooxanthellae.

Descritores: Brasil, Montastrea cavernosa; Dinoflagelados simbióticos; Zooxantelas.

\section{INTRODUCTION}

Studies on the temporal variations of population density and photosynthetic pigment content of the zooxanthellae of hermatypic corals are scarce, particularly throughout a complete annual cycle. Most previous studies have been done over relatively short temporal scales and do not provide sufficient data for reliable conclusions on the monthly and seasonal fluctuations of these characteristics of zooxanthellae (e.g. Fitt et al., 1993; Fitt \& Warner, 1995). Such aspects are nevertheless important for a detailed understanding of the functional dynamics of coral habitats, as well as the bleaching process. 
Most studies done on symbiotic dinoflagellates in coral have only attempted to explain specific functional processes such as photosynthesis, photoacclimation, and the contribution of zooxanthellae to coral metabolic requirements (Porter et al., 1984; Lesser, 2000). Further information is required on the population density and photosynthetic pigments of zooxanthellae throughout the year in the host tissues.

Using materials collected from reefs at Kaneohe Bay (Hawai), Stimson (1997) completed one of the first investigations emphasizing variations in the zooxanthellae density of Pocillopora damicornis throughout a complete annual cycle. Although the data set comprised several disparate years, the existence of seasonal effects on cell densities was demonstrated, with lower values in spring and summer than in winter. Verde \& McCloskey (1998) also provided data on the temporal variations in dinoflagellate densities, photosynthetic pigments, and mitotic index, in addition to information on production, respiration, and photophysiology of symbionts of the jellyfish Cassiopea xamachana in mangroves of Florida; but this work involved only two months: September, 1999 and January, 1993.

Significant reductions in the density and photosynthetic pigment content of zooxanthellae of hermatypic corals were reported by Brown et al. (1999) in the Indo-Pacific Ocean during the dry season. Fitt et al. (2000) also observed seasonal variations of zooxanthellae densities in five species of hermatypic corals, relating these to alterations in tissue biomass and coral bleaching. Seasonal fluctuations in the photosynthetic capacity of photosystem II were recently investigated by Warner et al. (2002) in three species of Montastrea in the Bahamas. This study also observed potential intra and interspecific differences at different depths.

In Brazil, the few existing studies on zooxanthellae were done in the northeast, emphasizing the use of dinoflagellates as a complement to the systematics of corals and hydrocorals (Amaral \& Costa, 1998; Costa \& Amaral, 2002), and also on some aspects of coral bleaching (Costa et al., 2001). C. F. Costa et al. (unp. data) studied monthly fluctuations in the number of cells and photosynthetic pigment concentration of the zooxanthellae of endemic Brazilian corals (Mussismilia harttii, M. hispida and Siderastrea stellata).

The present study aims to evaluate possible variations in population density and photosynthetic pigment content of zooxanthellae hosted by the coral Montastrea cavernosa, a species occurring in other regions of the world. This is the only species of Montastrea found in all Brazilian reef areas, except in the Cape of São Roque, Northern Brazil (Castro \& Pires, 2001). Although aspects of these symbionts have been investigated in other regions (Baker \& Rowan, 1997; Billinghurst et al., 1997), no data exist from Brazilian reefs.

\section{Materials ANd Methods}

Study site and collection of corals - Field studies were performed on the reefs of Picãozinho $\left(06^{\circ} 42^{\prime} 05^{\prime \prime} / 07^{\circ} 07^{\prime} 30^{\prime \prime} \mathrm{S}\right.$ and $034^{\circ} 48^{\prime} 37^{\prime \prime} / 34^{\circ} 50^{\prime} 00^{\prime \prime}$ W), Northeast Brazil. During each month between September 1999 and September 2000, three 10-cm diameter fragments of the coral Montastrea cavernosa were collected using a rock pick and hammer. Samples were placed in labeled plastic bags filled with seawater and transported to the laboratory in an insulated cooler.

Monthly water temperature and salinity were determined at the surface using a thermometer $\left( \pm 0.1^{\circ} \mathrm{C}\right)$ and an American Optical refractometer (model 10419), respectively. Pluviometric data were obtained from the LMRS - Laboratório de Meteorologia, Recursos Hídricos e Sensoriamento Remoto da Paraíba.

Zooxanthellae - The tissue covering $1 \mathrm{~cm}^{2}$ of each coral sample was waterpiked from each colony using a WaterPik ${ }^{\mathrm{TM}}$ with filtered seawater, the volumes of which were mechanically homogenized and recorded (Dustan, 1979). To avoid contamination in pigment analysis, all specimens were carefully checked for macroalgae adhered to the coral. The density of zooxanthellae was determined in a FuchsRosenthal chamber and four samples obtained from each homogenized preparation were examined. Pigments from subsamples were extracted in acetone $(90 \%)$ for analyzing chlorophyll- $a$ (Chl- $a$ ) and chlorophyll-c (Chl-c) and absorbencies read on a spectrophotometer. The contents were calculated using the method of Parsons \& Strickland (1963).

Statistical analyses - Statistical analyses were performed using STATISTICA version 4.0 software, at $5 \%$ level of significance. Homoscedasticity of variances of all data sets was confirmed using Levene's test. The means of variables measured over the year were compared by ANOVA and tukey HSD post hoc test. The Student's $t$-Test was applied to compare the means differences among the dry and rainy seasons. Pearson's correlation test was used for the linear correlation between population density and photosynthetic pigment content of symbionts.

\section{RESULTS}

The highest pluviometric values (total monthly) were recorded between April and July 2000 
(autumm/winter; rainy season), with a peak of $500 \mathrm{~mm}$ (Fig. 1). The temperature and salinity of superficial waters fluctuated throughout the year, with the highest values recorded during January and February (dry season). The lowest temperatures were recorded in September 1999 and June and July 2000, while the lowest salinity was during September 2000 (Fig. 1).

Cell density and photosynthetic pigment content varied throughout the study period but showed no correlation (Figs 2, 3; Pearson's correlation, $P>$ 0.05 ). The number of cells increased clearly and simultaneously to the contents of Chl- $a$ and Chl- $c$ only during January 2000 . These parameters were strongly reduced during the driest months (November and December 1999), at the beginning of the rainy season (February 2000) and during the highest rainfall (Figs 2, 3).
There were significant fluctuations in zooxanthellae density (ANOVA; $P<0.05$ ), with an annual mean $( \pm \mathrm{sd})$ of $2.6 \pm 1.2 \times 10^{6} \mathrm{~cm}^{-2}$. The difference between the maximum and minimum values observed was significant (tukey's Test; $P<$ 0.05 ). The variation in the numbers of cells obtained during the dry and rainy seasons was significant $(t-$ test; $P<0.05)$.

The photosynthetic pigment content showed significant fluctuations throughout the year (ANOVA; $P<0.05$ ), but the difference obtained between the dry and rainy seasons was not significant ( $t$-Test; $P>0.05)$. The means of zooxanthellae parameters obtained from the dry and rainy seasons showed a distinct pattern with an increase in the number of cells and a decrease in contents of Chl- $a$ and Chl- $c$ during the rainy season (Figs 3 and 4).

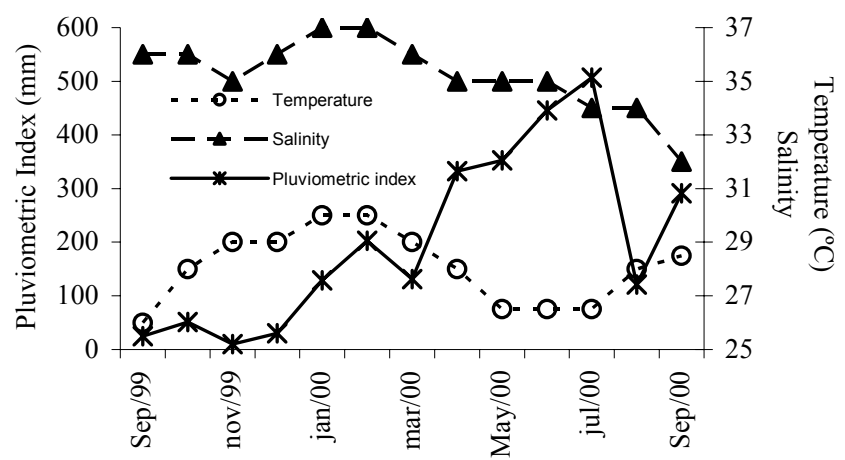

Fig. 1. Seasonal variations of pluviometric index (total monthly), water temperature and salinity of coral reefs at Picãozinho, Brazil, between September 1999 and 2000.

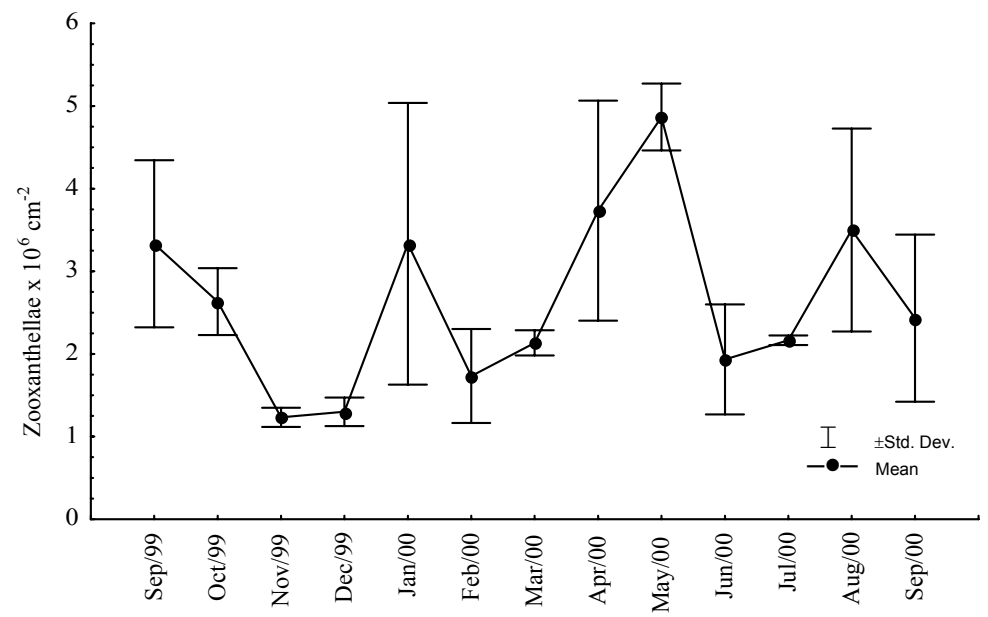

Fig. 2. Seasonal variations of zooxanthellae mean densities of Montastrea cavernosa, collected between September 1999 and 2000 in the reefs of Picãozinho, Brazil. 


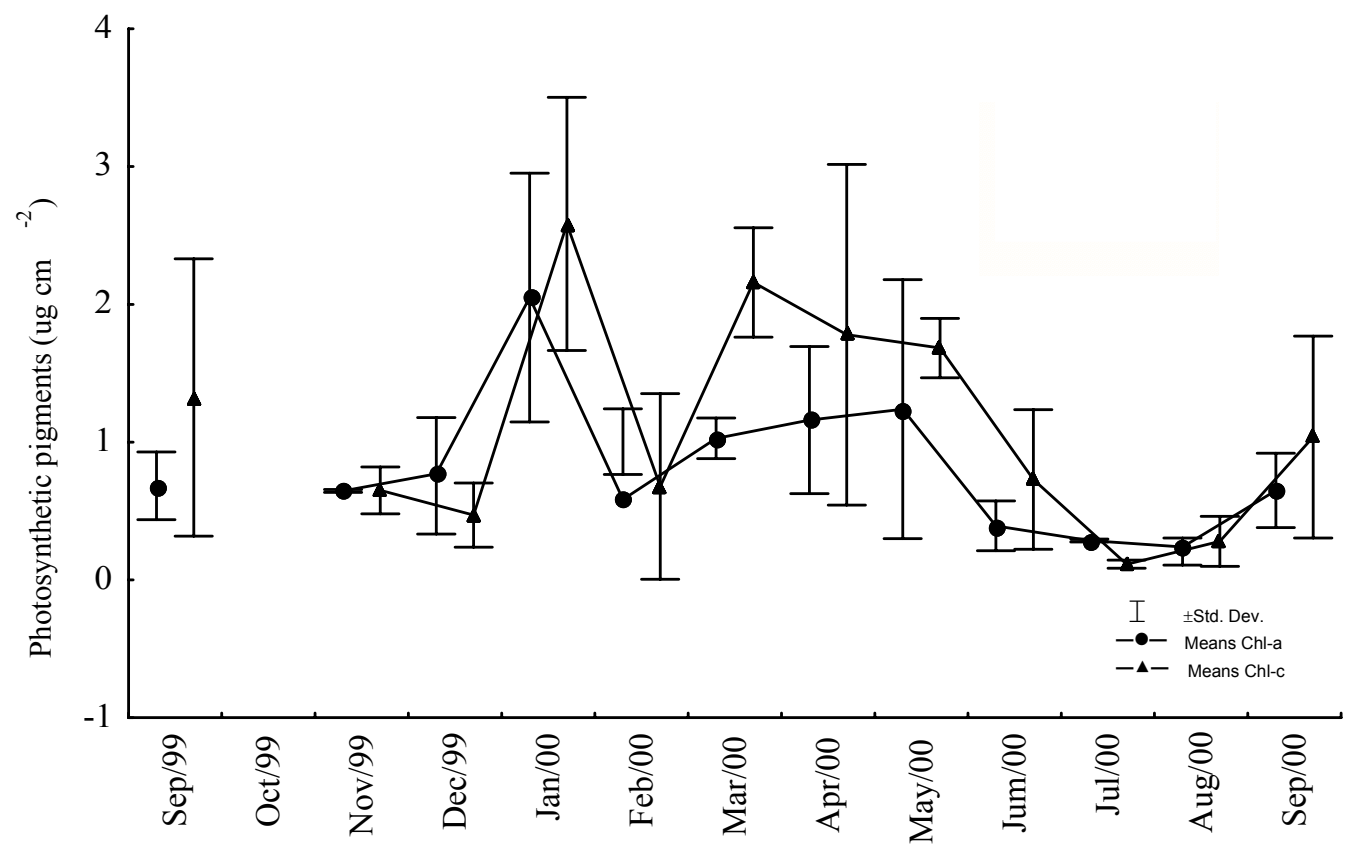

Fig. 3. Seasonal variations of chlorophyll- $a(\mathrm{Chl}-a)$ and chlorophyll-c (Chl-c) of Montastrea cavernosa zooxanthellae, collected between September 1999 and 2000 in the reefs of Picãozinho, Brazil.

\section{Discussion}

Light and water temperature have been reported as the most important factors affecting the physiology of zooxanthellae (Lombardi et al., 2000; Gorbunov et al., 2001; Glynn et al., 2001; Warner et al., 2002). These parameters are certainly coresponsible for the temporal variations of the zooxanthellae in shallow and coastal waters in the studied area, although light seems to have the most influence.

The data we obtained showed fluctuations of symbiotic parameters of Montastrea cavernosa throughout the year that were related to rainfall in the littoral region. Specifically, cells density and photosynthetic pigments showed higher values during first rains, but decreased strongly during the months of heavy rains (June and July). This pattern may be attributed to the continental runoff in the area, which affects water clarity during high rainfall, increasing stress on the coral. C. F. Costa et al. (unp. data) has also suggested that coastal erosion from cliffs southwards of the area also could increase sedimentation, owing to suspended materials carried northwards by tidal currents.

In other regions, seasonal changes in zooxanthellae frequently have been associated with water temperature, season and light conditions. But other factors also related to season may be important to control zooxanthellae densities hosted by corals, particularly in shallow water with large environmental fluctuations (Fagoonee et al., 1999). A clearly significant and predictable seasonal variation in cell numbers (normally higher in cool season) and pigment content (higher at the beginning of cool season) was found by Brown et al. (1999) in near-equatorial Thailand and by Stimson (1997) and Fagooneee et al. (1999) in zooxanthellae from coral species in the Pacific Ocean. Correlations from the Caribbean correlates include those observed by Fitt et al. (2000), relating zooxanthellae density fluctuations to changes in host tissue biomass.

We don't discount the seasonal influence of thermal conditions on the parameters of zooxanthellae in the studied area, but here these variations exhibit small differences between values of minimum and maximum temperature throughout the year, probably improving small actions on the symbiotic cells of corals. Temperature patterns are very stable in the region with the mean monthly air temperature varying by only about $4.5^{\circ} \mathrm{C}$ over the past thirty years (INMET - Instituto Nacional de Meteorologia, Laboratório de Meteorologia, Recursos Hídricos e Sensoriamento Remoto da Paraíba, LMRS/PB, http://www.lmrssemarh.ufpb.br). 

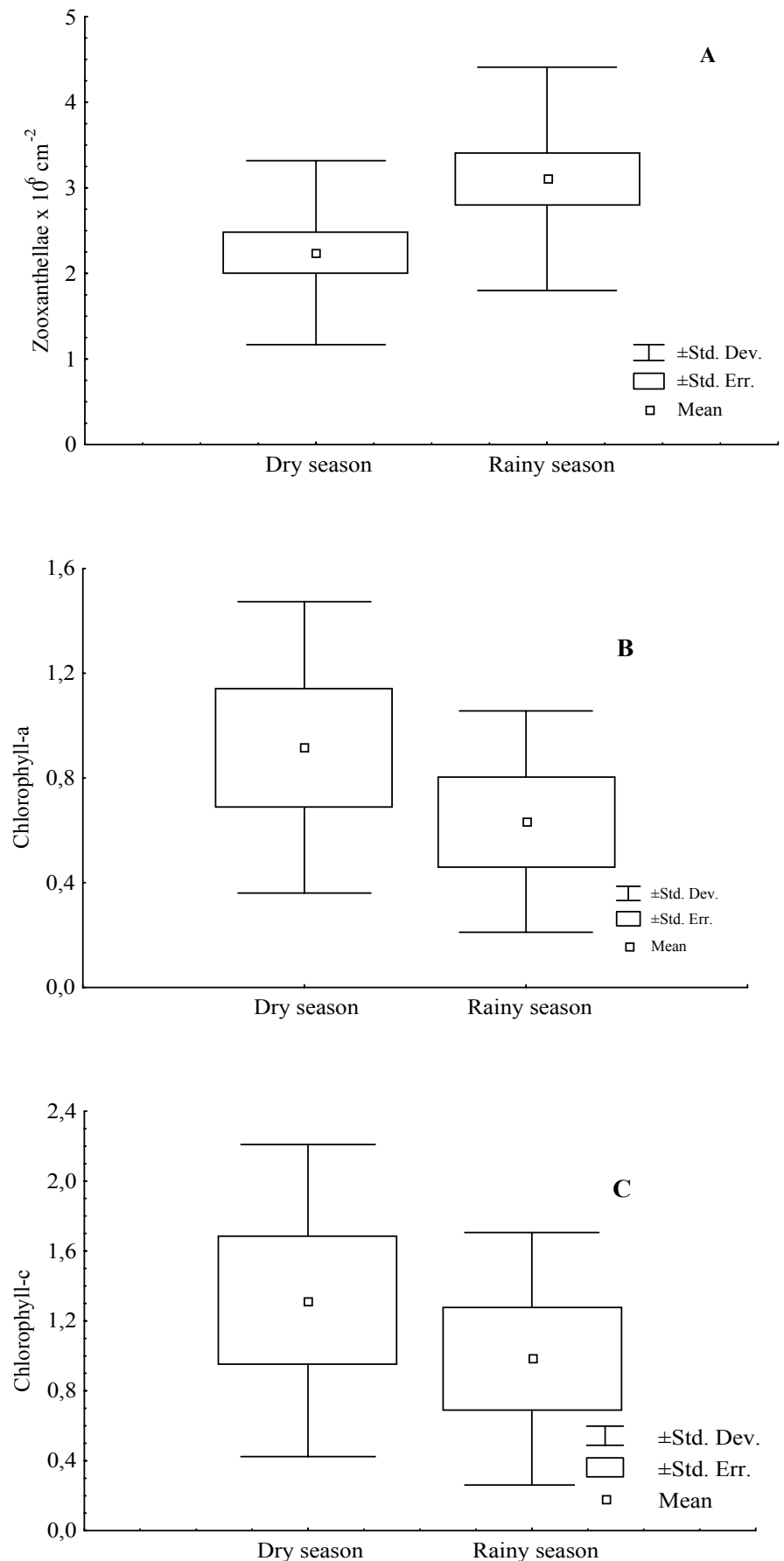

Fig. 4. Mean values of population density (A) and contents of chlorophyll- $a$ (B) and chlorophyll-c (C) $\left(\mu \mathrm{g} \mathrm{cm}^{-2}\right)$ from Montastrea cavernosa zooxanthellae, collected in the dry and rainy seasons in the reefs of Picãozinho, Brazil. 
When the mean values from dry season (September, 1999 to March, 2000) were compared with mean values from rainy season (April to July, 2000), a clear relationship was observed between photosynthetic pigment contents and cell densities, which decreased and increased, respectively during the rainy season. Such asynchrony between pigment content and cell densities seems to be uncommon in zooxanthellae data.

Any attenuation mechanism of light (refraction, reflection, and scattering) due to an increase in suspended materials during the rainy months probably explains why zooxanthellae lose their pigments despite the increase in cell numbers: a likely compensation of zooxanthellae during increased photic stress. Some researchers have reported photoprotection and photoacclimation processes carried out by zooxanthellae in response to excess and reduction of light, respectively (Gorbunov et al., 2001; Titlyanov et al., 2001).

The asynchrony we observed between cells densities and photosynthetic pigment contents may be due to: (1) the seasonal differences on cell physiology (e.g. the existence of many cells with 'accessory pigments' in relation to Chl- $a$, therefore more mature and less active), and (2) the existence of distinct symbionts strains in Montastrea cavernosa (Baker et al., 1997; Carlos et al., 2000), which probably show distinct physiological rates in coral tissues.

The peculiarities of coastal reefs in the region frequently could change water conditions, particularly the light owing to cliff erosion southwards and the lateral inputs of fine sediments. These factors could increase stress on coral species and so cause their zooxanthellae to instigate physiological and biochemical repairs. If this is the case, strains of zooxanthellae of $M$. cavernosa across Picãozinho reefs could present distinct successional patterns related to these environmental stresses. These hypotheses are speculative, however, and require more detailed testing.

\section{ACKNOWLEDGEMENTS}

This study was supported by CAPES/UFPB. We are grateful to "Núcleo de Estudos e Pesquisas dos Recursos do Mar (NEPREMAR/UFPB)" and the "Programa de Pós-Graduação em Ciências Biológicas (Zoologia)/UFPB" for laboratorial conditions and assistance. We are also grateful to Dr Breno Machado Grisi from the "Universidade Federal da Paraíba" and to Dr. Matt Broadhurst from NSW Fisheries Conservation Technology - Unit National Marine Science Center (Australia) for English assistance and to anonymous reviewers for comments improving the first drafts of this work.

\section{REFERENCES}

Amaral, F. D. \& Costa, C. F. 1998. Zooxantelas dos hidrocorais Millepora alcicornis e Millepora braziliensis e dos corais Favia gravida e Siderastrea stellata de Pernambuco. Trab. Oceanogr. Univ. Fed. PE., 26 (1):123-133.

Baker, A. C. \& Rowan, R. 1997. Diversity of symbiotic dinoflagellates (zooxanthellae) in scleractinian corals of the Caribbean and Eastern Pacific. Proc. 8th Int. Coral Reef Symp., 2:1301-1306.

Baker, A. C.; Rowan, R. \& Knowlton, N. 1997. Symbiosis ecology of two Caribbean acroporid corals. Proc. 8th Int. Coral Reef Symp., 2:1295-1300.

Billinghurst, Z.; Douglas, A. E. \& Trapido-Rosenthal, H. $\mathrm{G}$. 1997. On the genetic diversity of the symbiosis between the coral Montastrea cavernosa and zooxanthellae in Bermuda. Proc. 8th Int. Coral Reef Symp., 2:1291-1294.

Brown, B. E.; Dunne, R. P.; Ambarsari, I.; Le Tissier, M. D. A. \& Satapoomin, U. 1999. Seasonal fluctuations in environmental factors and variations in symbiotic algae and chlorophyll pigments in four Indo-Pacific coral species. Mar. Ecol. Prog. Ser., 195:117-124.

Carlos, A. A.; Baillie, B. \& Maruyama, T. 2000. Diversity of dinoflagellate symbionts (zooxanthellae) in a host individual. Mar. Ecol. Prog. Ser., 195::93-100.

Castro, C. B. \& Pires, D. O. 2001. Brazilian coral reefs: what we already know and what is still missing. Bull. mar. Sci., 69 (2):357-371.

Costa, C. F. \& Amaral, F. D. 2002. Density and size differences in zooxanthellae from five reef-building coral species from Brazil. Proc. 9th Int. Coral Reef Symp., 1:159-162.

Costa, C. F.; Amaral, F. D. \& Sassi, R. 2001. Branqueamento em Siderastrea stellata (Cnidaria, Scleractinia) da Praia de Gaibu - Pernambuco, Brasil. Rev. Nordestina Biol., 15:15-22.

Dustan, P. 1979. Distribution of zooxanthellae and photosynthetic chloroplast pigments of the reef-building coral Montastrea annularis Ellis and Solander in relation to depth on a West Indian coral reef. Bull. mar. Sci., 29:79-95.

Fagoonee, I.; Wilson, H. B.; Hassel, M. P. \& Turner, J. F. 1999. The dynamic of zooxanthellae populations: a long-term study in the field. Science, 283:843-845.

Fitt, W. K.; Spero, H. J.; Halas, J.; White, M. W. \& Porter, J. W. 1993. Recovery of the coral Montastrea annularis in the Florida keys after the 1987 Caribbean "Bleaching event". Coral Reefs, 12:57-64.

Fitt, W. K. \& Warner, M. E. 1995. Bleaching patterns of four species of Caribbean reef corals. Biol. Bull., 189:298-307.

Fitt, W. K.; McFarland, F. K.; Warner, M. E. \& Chilcoat, G. C. 2000. Seasonal patterns of tissue biomass and densities of symbiotic dinoflagellates in reef corals and relation to coral bleaching. Limnol. Oceanogr., 45:677685.

Gorbunov, M. Y.; Kolber, Z. S.; Lesser, M. P. \& Falkowski, P. G. 2001. Photosynthesis and photoprotection in symbiotic corals. Limnol. Oceanogr., 46(1):75-85. 
Glynn, P. W.; Maté, J. L.; Baker, A. C. \& Calderón, M. O. 2001. Coral bleaching and mortality in Panama and Ecuador during the 1997-1998 El NiÑo-Southern oscillation event: Spatial/temporal patterns and comparisons with the 1982-1983 event. Bull. mar. Sci., 69(1):79-109.

Lesser, M. P. 2000. Depth-dependent photoacclimatization to solar ultraviolet radiation in the Caribbean coral Montastrea faveolata. Mar. Ecol. Prog. Ser., 192:137-151.

Lombardi, M. R.; Lesser, M. P. \& Gorbunov, M. Y. 2000. Fast repetition rate (FRR) fluorometry: variability of chlorophyll $a$ fluorescence yields in colonies of the corals, Montastrea faveolata (w.) and Diploria labyrinthiformes (h.) recovering from bleaching. J. expl mar. Biol. Ecol., 252:75-84

Parsons, T. R. \& Strickland, J. D. H. 1963. Discussion of spectrophotometric determination of marine plant pigments, with revised equations for ascertaining chlorophylls and carotenoids. J. Mar. Res., 21:155-163.

Porter, J. W.; Muscatine, L.; Dubinsky, Z. \& Falhowski, P. G. 1984. Primary production and photoadaptation in light-shade-adapted colonies of the symbiotic coral Stylophora pistillata. Proc. R. Soc. Lond., B 222:161-180.
Stimson, J. 1997. The annual cycle of density of zooxanthellae in the tissue of field and laboratory-held Pocillopora damicornis (Linnaeus). J. expl mar. Biol. Ecol., 214:35-48.

Titlyanov, E. A.; Titlyanov, T. V.; Yamazato, K. Y. \& Woesik, R. V. 2001. Photo-acclimation dynamics of the coral Stylophora pistillata to low and extremely low light. J. expl mar. Biol. Ecol., 263:211-225.

Verde, E. A. \& McCloskey, L. R. 1998. Production, respiration, and photophysiology of the mangrove jellyfish Cassiopea xamachana symbiotic with zooxanthellae: effect of jellyfish size and season. Mar. Ecol. Prog. Ser., 168:147-162.

Warner, M. E.; Chilcoat, G. C.; McFarland, F. K. \& Fitt, W. K. 2002. Seasonal fluctuations in the photosynthetic capacity of photosystem II in symbiotic dinoflagellates in the Caribbean reef-building coral Montastrea. Mar. Biol., 141:31-38.

(Manuscript received 13 March 2003; revised 25 September; accepted 08 March 2004) 